\title{
On the run: free-living mushroom corals avoiding interaction with sponges
}

\author{
B. W. Hoeksema $\cdot$ N. J. de Voogd
}

Received: 28 June 2011/ Accepted: 24 November 2011/Published online: 8 December 2011

(C) The Author(s) 2011. This article is published with open access at Springerlink.com

\begin{abstract}
Individuals of the free-living mushroom coral Heliofungia fralinae moved away when placed in contact with fragments of the toxic haplosclerid sponge Callyspongia (Euplacella) biru. This reaction was not evoked by three other sponge species. The experiment demonstrated that mobility of mushroom corals helps them to flee from organisms that secrete secondary metabolites in competition for space.
\end{abstract}

Keywords Competition - Interspecific aggression · Mobility · Toxicity

\section{Introduction}

Various groups of coral reef organisms employ interspecific aggression in competition for space. Scleractinian corals may come into contact with other organisms, such as algae (River and Edmunds 2001; Jompa and McCook 2002, 2003; Nugues and Bak 2006; Haas et al. 2010; Benzoni et al. 2011), ascidians (Bak et al. 1981, 1996; Sommer et al. 2009), barnacles (Benzoni et al. 2010), corallimorpharians (Chadwick 1991; Chadwick and Adams 1991; Langmead and Chadwick-Furman 1999; Kuguru et al. 2004), polychaetes (Samini Namin et al. 2010), soft corals (Sammarco et al. 1983; Dai 1990), and particularly by sponges (de Voogd et al. 2004, 2005; Coles and Bolick 2007; de Voogd 2007; Benzoni et al. 2008) and may be overgrown and even

Communicated by Biology Editor Dr. Hugh Sweatman

B. W. Hoeksema $(\bowtie) \cdot$ N. J. de Voogd

Department of Marine Zoology, Netherlands Centre for

Biodiversity Naturalis, P.O. Box 9517, 2300 RA Leiden,

The Netherlands

e-mail: bert.hoeksema@ncbnaturalis.nl killed by them. Scleractinian coral species also show aggressive reactions to one another, which may depend on coral size, secretion of bioactive compounds, and the presence of sweeper tentacles (Sheppard 1981; Bak et al. 1982; Koh and Sweatman 2000; Lapid et al. 2004; Lapid and Chadwick 2006; Chadwick and Morrow 2011).

Mushroom corals (Fungiidae) usually play the role of aggressor in interspecific coral interactions (Sheppard 1979; Cope 1981; Thomason and Brown 1986; Chadwick 1988; Chadwick-Furman and Loya 1992; Abelson and Loya 1999). They are not known to damage each other but when they overtop each other in multi-species assemblages (Hoeksema and Moka 1989; Hoeksema 1991; Elahi 2008; Hoeksema and Koh 2009; Hoeksema and Matthews 2011), they may compete for space, light and food. The chance for frequent contact with other organisms, such as sponges, is especially high in free-living fungiids, which detach themselves from the substrate and become mobile (Chadwick 1988; Hoeksema 1988; Chadwick-Furman and Loya 1992; Yamashiro and Nishihira 1995; Hoeksema and Yeemin 2011). Sponges may produce toxic compounds that play an important role in competition for space with scleractinian corals (Aerts and van Soest 1997; de Voogd et al. 2004). Some species of sponges can also harm corals by overgrowing them or by boring into them (Aerts 1998; Schönberg and Wilkinson 2001; de Voogd et al. 2004, 2005; López-Victoria et al. 2006; González-Rivero et al. 2011). Here, we examined the consequences of free-living mushroom corals being forced into contact with fragments of a range of sponge species with varying degrees of toxicity.

\section{Materials and methods}

The study site was at the reef base on the northwest side of Samalona I. $\left(05^{\circ} 07.326^{\prime}\right.$ S $119^{\circ} 20.410^{\prime}$ E) in the Spermonde 
Archipelago, $7 \mathrm{~km}$ off Makassar, SW Sulawesi, Indonesia. Mushroom corals and sponges are diverse in this area (Hoeksema and Moka 1989; Cleary et al. 2005; Becking et al. 2006; de Voogd et al. 2006). Four sponge species were selected on the basis of their abundance and known bioactivity (de Voogd 2005; de Voogd et al. 2006; Cleary and de Voogd 2007). In order of decreasing bioactivity of crude extracts, the target species were Callyspongia biru de Voogd, $2004>$ Amphimedon paraviridis (Fromont, 1993) > Niphates olemda (De Laubenfels, 1934) > Aaptos suberitoides (Brøndsted, 1934) (de Voogd 2005).

The free-living mushroom coral Heliofungia fralinae (Nemenzo, 1955) was chosen as potential spatial competitor. This species is able to move across the reef surface and commonly reproduces asexually by budding which may result in dense aggregations that cover the substrate to the exclusion of other reef organisms (Hoeksema 1990, 2004)

In June 2001, 14 similarly sized fragments (length $10-12 \mathrm{~cm}$ ) of each sponge target species were collected at a depth of $12 \mathrm{~m}$. Thin plastic-coated electric cable was used to attach them to nylon fish net stretched over a $100 \times 70 \mathrm{~cm}$ rectangular frame of PVC tubes (Fig. 1a). After an adjustment period of 10 weeks, 40 individuals of $H$. fralinae $(\varnothing$ $12-15 \mathrm{~cm}$ ) were collected. Ten corals were tied closely next to an equal number of sponge fragments attached to PVCframes with cable to keep the coral and sponge in direct contact with each other (Fig. 1). Two complete fragments per sponge species were collected at the start of the experiment and two control fragments were left on the frame without contact with corals until collection at the end of the experiment. The fragments of each sponge species were scheduled to be collected for toxicity tests, two at each of five times over the experiment: $\mathrm{T} 1=24 \mathrm{~h}, \mathrm{~T} 2=48 \mathrm{~h}, \mathrm{~T} 3=$ 7 days, $\mathrm{T} 4=14$ days, and $\mathrm{T} 5=21$ days. The toxicity test was designed to see whether forced contact with a spatial competitor would cause a change in toxicity of the sponges (e.g., Richelle-Maurer et al. 2003).

Changes in bioactivity of the crude extract of the Callyspongia biru fragments were assessed using the brine shrimp
(Artemia salina) lethality test. This is an effective assay for bioactive activity of secondary metabolites from terrestrial and marine organisms (Meyer et al. 1982) and can be used when alternative bioassays are not available (Caldwell et al. 2003). Brine shrimp larvae are known to be sensitive to crude sponge extracts (Richelle-Maurer et al. 2002).

The crude extract of the sponge was obtained as follows: sponge fragments were cut in small pieces and extracted in $\pm 50 \mathrm{ml}$ methanol for $24 \mathrm{~h}$; this was repeated three times. The filtrates from each species were combined and placed in a cooled evaporator for approximately $48 \mathrm{~h}$. The bioactivity of the resulting extract was expressed with the LC $_{50}$ (mortality of $\geq 50 \%$ Artemia nauplii after exposure to dilutions of the crude extract of C. biru; see de Voogd 2005). Bioactivity was based on five categories: very strong $=\mathrm{LC} 50 \leq 1 \mathrm{mg} \mathrm{l}^{-1}$, strong $=\mathrm{LC} 50$ between 1 and $5 \mathrm{mg} \mathrm{l}^{-1}$, moderate $=$ LC50 between 5 and $10 \mathrm{mg} \mathrm{l}^{-1}$ and weak $=$ LC50 between 10 and $20 \mathrm{mg} \mathrm{l}^{-1}$.

\section{Results and discussion}

After 24 (T1) and $48 \mathrm{~h}$ (T2), two of the complete sponge fragments were collected from the frames for toxicity measurements, while the corals were placed back on the reef. After 7 days (T3), five of the six remaining mushroom corals that had been in contact with $C$. biru had freed themselves from the cable and moved away, thereby terminating the experiment (Fig. 1b). The corals moved ca. $5-20 \mathrm{~cm}$ away from the sponges. One of the corals had even moved off the frame. The crude extract from $C$. biru fragments that were in contact with corals was highly toxic (very strong and strong) compared with extract from the control sponges (moderate and weak). The mushroom corals that were placed in contact with fragments of the three other sponge species remained tied in place for the whole experimental method.

Mobility of mushroom corals helps them to disperse and occupy vacant space, to avoid burial in soft sediments, and to escape competition with other corals (Chadwick 1988;
Fig. 1 Heliofungia fralinae corals in experimental set-up at Samalona I., Spermonde Archipelago. a Corals $(\varnothing$ $12-15 \mathrm{~cm}$ ) placed in contact with fragments of the sponge Callyspongia biru (start of experiment, T0). b Some corals are escaping, only number 1 remains fixed (T3)
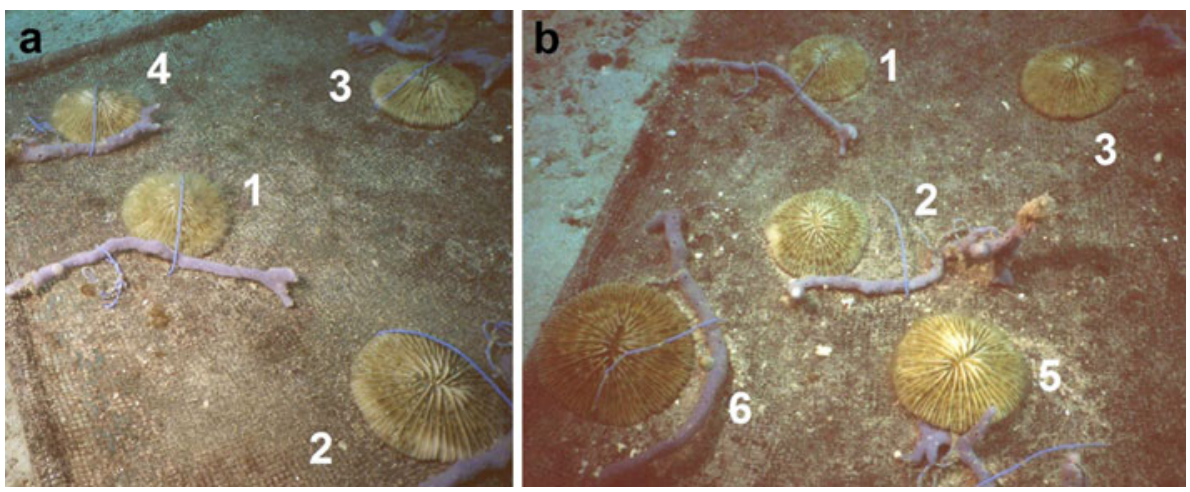
Hoeksema 1988). In the present study, individuals of $H$. fralinae were able to unfasten themselves and move away from toxic sponges of the species $C$. biru and so survive.

In another confrontation experiment (de Voogd et al. 2005), where specimens of the mushroom coral Fungia fungites (Linnaeus, 1758) were placed in contact with fragments of $C$. biru, none of the fungiids escaped but some of them showed white spots. This suggests that exudation of secondary metabolites and competitive dominance of the sponge may elicit bleaching as a stress response in the corals. Although competition has not been explicitly seen to cause bleaching among corals (Brown 1997), there are indications that it may play a role in coralalgal interactions (McCook et al. 2001). F. fungites is known to be an aggressive competitor for space (Hildemann et al. 1975; Thomason and Brown 1986), but no such information is available for the less common $H$. fralinae. These two species are less closely related than has been previously assumed (Gittenberger et al. 2011).

This is the first report of mushroom coral movements caused by interaction with a non-coral invertebrate. $H$. fralinae has a subordinate role but little is known about interspecific interactions with other organisms. Parasitic and commensal animals have never been recorded from $H$. fralinae, in contrast to most other mushroom coral species, and in particular its congener, H. actiniformis (Quoy and Gaimard, 1833), one of the most hospitable coral species recorded so far (Bos 2011; Hoeksema and Fransen 2011; Hoeksema et al. 2011).

The capacity of $H$. fralinae to inflate its polyp, like H. actiniformis (see Abe 1939), may have helped the corals to wriggle free from the ties. Small individuals of the mushroom coral Lobactis scutaria (Lamarck, 1801) are able to flee from neighbouring corals by nocturnal polyp expansion and by pushing, while larger and heavier individuals remaining in contact with coral neighbours can inflict damage on their tissue by the secretion of mucus containing nematocysts (Chadwick 1988; Chadwick-Furman and Loya 1992). Large mushroom corals do not move fast although they may be able to right themselves (Hoeksema 1988).

Polyp inflation, which may help mushroom corals to free themselves from sediment after burial, may also serve as a dispersal mechanism. This may prevent them being overtopped in large aggregations (Hoeksema 2004). Because mobile corals may more frequently come into contact with other organisms, aggressive behaviour would be beneficial. $H$. fralinae corals are likely to survive interactions with other species, either because of their aggressive behaviour or their flight response.

Acknowledgments The Netherlands Foundation for the Advancement of Tropical Research (WOTRO grant W84-474) funded the research. It was supported by the Indonesian Institute of Science and Hasanuddin University. Prof. Dr. Alfian Noor gave logistical assistance. Ms. Vera Bavinck and Ms. Lisa Becking assisted with the fieldwork. Prof. J.C. Braekman helped with various aspects on the sponge chemistry. We thank anonymous reviewers for their constructive remarks.

Open Access This article is distributed under the terms of the Creative Commons Attribution Noncommercial License which permits any noncommercial use, distribution, and reproduction in any medium, provided the original author(s) and source are credited.

\section{References}

Abe N (1939) Migration and righting reaction of the coral, Fungia actiniformis var. palawensis Döderlein. Palao Trop Biol Sta Stud 4:671-694

Abelson A, Loya Y (1999) Interspecific aggression among stony corals in Eilat, Red Sea: a hierarchy of aggression ability and related parameters. Bull Mar Sci 65:851-860

Aerts LAM (1998) Sponge/coral interactions in Caribbean reefs: analysis of overgrowth patterns in relation to species identity and cover. Mar Ecol Prog Ser 175:241-249

Aerts LAM, van Soest RWM (1997) Quantification of sponge/coral interactions in a physically stressed reef community, NE Colombia. Mar Ecol Prog Ser 148:125-134

Bak RPM, Sybesma J, van Duyl FC (1981) The ecology of the tropical compound ascidian Trididemnum solidum II. Abundance, growth and survival. Mar Ecol Prog Ser 6:43-52

Bak RPM, Termaat RM, Dekker R (1982) Complexity of coral interactions: Influence of time, location of interaction and epifauna. Mar Biol 69:215-222

Bak RPM, Lambrechts DYM, Joenje M, Nieuwland G, van Veghel MLJ (1996) Long-term changes on coral reefs in booming populations of a competitive colonial ascidian. Mar Ecol Prog Ser 133:303-306

Becking LE, Cleary DFR, de Voogd NJ, Renema W, de Beer M, van Soest RWM, Hoeksema BW (2006) Beta diversity of tropical marine benthic assemblages in the Spermonde Archipelago, Indonesia. Mar Ecol 27:76-88

Benzoni F, Calcinai B, Eisinger M, Klaus R (2008) Coral disease mimic: sponge attacks Porites lutea in Yemen. Coral Reefs 27:695

Benzoni F, Pichon M, Galli P (2010) Pink spots on Porites: not always a coral disease. Coral Reefs 29:153

Benzoni F, Basso D, Caragnano A, Rodondi G (2011) Hydrolithon spp. (Rhodophyta, Corallinales) overgrow live corals (Cnidaria, Scleractinia) in Yemen. Mar Biol 158:2419-2428

Bos AR (2011) Symbiotic fishes (Gobiidae and Labridae) of the mushroom coral Heliofungia actiniformis (Scleractinia; Fungiidae). Coral Reefs. doi:10.1007/s00338-011-0834-3

Brown BE (1997) Coral bleaching: causes and consequences. Coral Reefs 16(Suppl):S129-S138

Caldwell GS, Bentley MG, Olive PJW (2003) The use of a brine shrimp (Artemia salina) bioassay to assess the toxicity of diatom extracts and short chain aldehydes. Toxicon 42:301-306

Chadwick NE (1988) Competition and locomotion in a free-living fungiid coral. J Exp Mar Biol Ecol 123:189-200

Chadwick NE (1991) Spatial distribution and the effects of competition on some temperate Scleractinia and Corallimorpharia. Mar Ecol Prog Ser 70:39-48

Chadwick NE, Adams C (1991) Locomotion, asexual reproduction, and killing of corals by the corallimorpharian Corynactis californica. Hydrobiologia 216(217):263-269 
Chadwick NE, Morrow KM (2011) Competition among sessile organisms on coral reefs. In: Dubinsky Z, Stambler N (eds) Coral reefs: an ecosystem in transition. Springer, Dordrecht, pp 347-371

Chadwick-Furman NE, Loya Y (1992) Migration, habitat use, and competition among mobile corals (Scleractinia: Fungiidae) in the Gulf of Eilat, Red Sea. Mar Biol 114:617-623

Cleary DFR, de Voogd NJ (2007) Environmental determination of sponge assemblages in the Spermonde Archipelago, Indonesia. J Mar Biol Assoc UK 87:1669-1676

Cleary DFR, de Voogd NJ, Becking LE, Renema W, de Beer M, van Soest RWM, Hoeksema BW (2005) Variation in the diversity and composition of benthic taxa as a function of distance offshore, depth and exposure in the Spermonde Archipelago. Estuar Coast Shelf Sci 65:557-570

Coles S, Bolick H (2007) Invasive introduced sponge Mycale grandis overgrows reef corals in Kane'ohe Bay, O'ahu, Hawai'i. Coral Reefs 26:911

Cope M (1981) Interspecific coral interactions in Hong Kong. Proc 4th Int Coral Reef Symp 2:357-362

Dai CF (1990) Interspecific competition in Taiwanese corals with special reference to interactions between alcyonaceans and scleractinians. Mar Ecol Prog Ser 60:291-297

de Voogd NJ (2004) Callyspongia (Euplacella) biru spec. nov. (Porifera: Demospongiae: Haplosclerida) from Indonesia. Zool Meded 78:477-483

de Voogd NJ (2005) Indonesian sponges: Biodiversity and mariculture potential. PhD-thesis, Univ Amsterdam

de Voogd NJ (2007) The mariculture potential of the Indonesian reefdwelling sponge Callyspongia (Euplacella) biru: growth, survival and bioactive compounds. Aquaculture 262:54-64

de Voogd NJ, Becking LE, Noor A, Hoeksema BW, van Soest RWM (2004) Sponge interactions with spatial competitors in SW Sulawesi. Boll Mus Ist Biol Univ Genova 68:253-261

de Voogd NJ, Haftka JJH, Hoeksema BW (2005) Evaluation of the ecological function of amphitoxin in the reef-dwelling sponge Callyspongia (Euplacella) biru (Haplosclerida: Callyspongiidae) at southwest Sulawesi, Indonesia. Contrib Zool 74:53-61

de Voogd NJ, Cleary DFR, Hoeksema BW, Noor A, van Soest RWM (2006) Sponge beta diversity in the Spermonde Archipelago, Indonesia. Mar Ecol Prog Ser 309:131-142

Elahi R (2008) Effects of aggregation and species identity on the growth and behavior of mushroom corals. Coral Reefs 27: 881-885

Gittenberger A, Reijnen BT, Hoeksema BW (2011) A molecularly based phylogeny reconstruction of mushroom corals (Scleractinia: Fungiidae) with taxonomic consequences and evolutionary implications for life history traits. Contrib Zool 80:107-132

González-Rivero M, Yakob L, Mumby PJ (2011) The role of sponge competition on coral reef alternative steady states. Ecol Model 222:1847-1853

Haas A, El-Zibdah M, Wild C (2010) Seasonal monitoring of coralalgae interactions in fringing reefs of the Gulf of Aqaba, Northern Red Sea. Coral Reefs 29:93-103

Hildemann WH, Linthicum DS, Vann DC (1975) Transplantation and immunoincompatibility reactions among reef-building corals. Immunogenetics 2:269-284

Hoeksema BW (1988) Mobility of free-living fungiid corals (Scleractinia), a dispersion mechanism and survival strategy in dynamic reef habitats. Proc 6th Int Coral Reef Symp 2:715-720

Hoeksema BW (1990) Systematics and ecology of mushroom corals (Scleractinia: Fungiidae). PhD. Thesis, Leiden Univ

Hoeksema BW (1991) Control of bleaching in mushroom coral populations (Scleractinia: Fungiidae) in the Java Sea: stress tolerance and interference by life history strategy. Mar Ecol Prog Ser 74:225-237
Hoeksema BW (2004) Impact of budding on free-living corals at East Kalimantan, Indonesia. Coral Reefs 23:492

Hoeksema BW, Fransen CHJM (2011) Space partitioning by symbiotic shrimp species cohabitating in the mushroom coral Heliofungia actiniformis at Semporna, eastern Sabah. Coral Reefs 30:519

Hoeksema BW, Koh EGL (2009) Depauperation of the mushroom coral fauna (Fungiidae) of Singapore (1860s-2006) in changing reef conditions. Raffles Bull Zool Suppl 22:91-101

Hoeksema BW, Matthews JL (2011) Contrasting bleaching patterns in mushroom coral assemblages at Koh Tao, Gulf of Thailand. Coral Reefs 30:95

Hoeksema BW, Moka W (1989) Species assemblages and ecomorph variation of mushroom corals (Scleractinia: Fungiidae) related to reef habitats in the Flores Sea. Neth J Sea Res 23:149-160

Hoeksema BW, Yeemin T (2011) Late detachment conceals serial budding by the free-living coral Fungia fungites in the Inner Gulf of Thailand. Coral Reefs 30:975

Hoeksema BW, van der Meij SET, Fransen CHJM (2011). The mushroom coral as a habitat. J Mar Biol Assoc UK. doi:10.1017/ S0025315411001445

Jompa J, McCook LJ (2002) Effects of competition and herbivory on interactions between a hard coral and a brown alga. J Exp Mar Biol Ecol 271:25-39

Jompa J, McCook LJ (2003) Contrasting effects of turf algae on corals: massive Porites spp. are unaffected by mixed species turfs, but are killed by the red alga Anotrichium tenue. Mar Ecol Prog Ser 258:79-86

Koh EGL, Sweatman H (2000) Chemical warfare among scleractinians:bioactive natural products from Tubastraea faulkneri Wells kill larvae of potential competitors. J Exp Mar Biol Ecol 251: $141-160$

Kuguru BL, Mgaya YD, Öhman MC, Wagner GM (2004) The reef environment and competitive success in the Corallimorpharia. Mar Biol 145:875-884

Langmead O, Chadwick-Furman NE (1999) Marginal tentacles of the corallimorpharian Rhodactis rhodostoma. 1. Role in competition for space. Mar Biol 134:479-489

Lapid ED, Chadwick NE (2006) Long-term effects of competition on coral growth and sweeper tentacle development. Mar Ecol Prog Ser 313:115-123

Lapid ED, Wielgus J, Chadwick-Furman NE (2004) Sweeper tentacles of the brain coral Platygyra daedalea: induced development and effects on competitors. Mar Ecol Prog Ser 282: $161-171$

López-Victoria M, Zea S, Weil E (2006) Competition for space between encrusting excavating Caribbean sponges and other coral reef organisms. Mar Ecol Prog Ser 312:113-121

McCook LJ, Jompa J, Diaz-Pulido G (2001) Competition between corals and algae on coral reefs: A review of available evidence and mechanisms. Coral Reefs 19:400-417

Meyer BN, Ferrigni NR, Putnam JE, Jacobsen LB, Nichols DE, McLaughlin JL (1982) Brine shrimp-A convenient general bioassay for active plant constituents. Planta Med 45:31-34

Nugues MM, Bak RPM (2006) Differential competitive abilities between Caribbean coral species and a brown alga: a year of experiments and a long-term perspective. Mar Ecol Prog Ser 315: $75-86$

Richelle-Maurer E, Braekman JC, de Kluijver MMJ, Devijver C, Feio S, Gaspar H, Gomez R, Medeiros MA, Tavares R, van de Vijver G, van Soest RWM (2002) Distribution of antimicrobial and cytotoxic activities in marine sponges. Boll Mus Biol Univ Genova 66-67:165-166

Richelle-Maurer E, de Kluiver MJ, Feio S, Gaudêncio S, Gaspar H, Gomez R, Taveres R, van de Vijver G, van Soest RWM (2003) Localization and ecological significance of oroidin and sceptrin 
in the Caribbean sponge Agelas conifer. Biochem Syst Ecol 31:1073-1091

River GF, Edmunds PJ (2001) Mechanisms of interaction between macroalgae and scleractinians on a coral reef in Jamaica. J Exp Mar Biol Ecol 261:159-172

Samini Namin K, Risk MJ, Hoeksema BW, Zohari Z, Rezai H (2010) Coral mortality and serpulid infestations associated with red tide, in the Persian Gulf. Coral Reefs 29:509

Sammarco PW, Coll JC, La Barre SC, Willis B (1983) Competitive strategies of soft corals (Coelenterata: Octocorallia): allelopathic effects on selected scleractinian corals. Coral Reefs 1:173-178

Schönberg CHL, Wilkinson CR (2001) Induced colonization of corals by a clionid bioeroding sponge. Coral Reefs 20:69-76
Sheppard CRC (1979) Interspecific aggression between reef corals with reference to their distribution. Mar Ecol Prog Ser 1: 237-247

Sheppard CRC (1981) 'Reach' of aggressively interacting corals, and relative importance of interactions at different depths. Proc 4th Int Coral Reef Symp 2:363-368

Sommer B, Harrison PL, Scheffers SR (2009) Aggressive colonial ascidian impacting deep coral reefs at Bonaire, Netherlands Antilles. Coral Reefs 29:245

Thomason JC, Brown BE (1986) The cnidom: an index of aggressive proficiency in scleractinian corals. Coral Reefs 5:93-101

Yamashiro H, Nishihira M (1995) Phototaxis in Fungiidae corals (Scleractinia). Mar Biol 124:461-465 